candidate for a year's work in the United Kingdom. The stipend may range from $£ 900$ to $£ 1,300$ per annum (or the equivalent sums in Danish kroner), travelling and some incidental expenses being provided in addition. The tenure of the awards will start in September 1961. Further information can be obtained from the Assistant Scientific Secretary of the Wellcome Trust, 52 Queen Anne Street, London, W.1. Applications must be submitted before April 30 .

\section{Medical Research Fund for Australia and New Zealand}

A FUND has been established by the Life Offices' Association for Australasia to promote and assist scientific and medical research. For the present it is intended to use the resources of the Fund to stimulate and support research in the field of cardiovascular function and disease. Grants from the Fund will be made as follows : grants in aid, which will be given to non-profit institutions with basic facilities and qualified personnel for medical research, and will range from $£ 1,000$ to $£ 3,000$; research fellowships, which will be open to medical graduates or those with equivalent seientific training, and will fall into two categories: $(a)$ fellowships taken up in Australia and New Zealand for a period of one year $(£ 2,200$ $£ 2,500$ p.a.); (b) travelling fellowships, for a period of two years abroad, followed by a third year in an approved institution in Australia or New Zealand $(£ 2,500-£ 3,000$ p.a.). Further information and application forms can be obtained from Dr. H. M. Whyte, Life Insurance Medical Research Fund of Australia and New Zealand, 87 Pitt Street, Sydney. Applications for all awards must be received by July 1 .

\section{André Mayer Food and Agriculture Fellowships}

The Food and Agriculture Organization of the United Nations has announced that it will offer ten or twelve André Mayer fellowships in 1961. These awards will be made under the following two groups : research, for unusually promising persons with research experience behind them who would offer a guarantee for the carrying out of independent research work; research training, for younger and promising individuals who have demonstrated an inclination towards, and an aptitude for, research work. Due consideration will be given to geographical distribution, to ensure that a proportion of the awards is given to candidates from countries where research facilities are not highly developed and the need for trained resenreh workers is great. The subjects presented must be in relation to the Organization's activities, which comprise: land and water development, plant production and protection, animal production and health, rural institutions and services, fisheries, forestry and forest products, nutrition (nonmedical), atomic energy in food and agriculture, agricultural economies (commodities, statistics, economic analysis). Further information can be obtained from the National Committee for the United Kingdom of the Food and Agriculture Organization, Ministry of Agriculture, Fisheries and Food, Whitehall Place (East Block), London, S.W.1. The closing date for application is April 30.

\section{University News :}

Birmingham

THE following appointments have been announced: Dr. M. Z. Atassi, to be Research Fellow in the Depart- ment of Chemistry; Dr. B. Cockayne, at present Research Fellow in the Department of Physical Metallurgy, to be lecturer in the Department of Physical Metallurgy; M. J. Hamlin, to be lecturer in the Department of Civil Engineering; Dr. D. A. Smith, to be lecturer in the Department of Microbiology. The title of reader in neuropharmacology has been conferred on Dr. P. B. Bradley, senior lecturer in electrophysiology in the Department of Experimental Psychiatry.

Edinburgh

Dr. Dugald Gardner has been appointed as senior lecturer in pathology. Dr. R. C. Dorf has been appointed as a lecturer in electrical engineering, and T. Astarabadi as a lecturer in physiology.

\section{Announcements}

DR. C. J. JACKsoN has been appointed chairman of the Water Pollution Research Board for the period April 1, 1961-March 31, 1966, in succession to Dr. F. H. Garner, who completed his term of office on March 31. Dr. Jackson is in charge of all water pollution problems for the Distillers Co., Ltd., both on the potable and industrial sides.

Prof. J. A. Gondkoor has been appointed managing director for research at the Reactor Centrum Nederland, where he was previously in charge of the Physics Department. Prof. Goedkoop has been at the Centrum since its foundation in 1955 . For some years he directed the physics research at the NorwegianNetherlands Joint Establishment for Nuclear Energy Research (JENER) at Kjeller, Norway. He is also a part-time professor at the Leyden State University.

A JoInt meeting of the Challenger Society and representatives from the Marine Laboratories (Development Commissioners' Scheme) will be held at the Royal Dublin Society, Ballsbridge, Dublin, during May 24-25. Further information can be obtained from the Challenger Society, o/o Dr. A. E. J. Went, Fisheries Division, Department of Lands, 3 Cathal Brugha Street, Dublin.

THE Nutrition Society (Scottish Group) is holding a symposium on "The Relative Values of Animal and Vegetable Fats in Nutrition" at the Physiology Lecture Theatre, Queen's College, Dundee, on April 22. Further information can be obtained from the honorary secretary of the Scottish Group of the Nutrition Society, Dr. J. Davidson, Rowett Research Institute, Bucksburn, Aberdeen.

THE annual general meeting of the Oil and Fats Group of the Society of Chemical Industry is to be held at Liverpool on April 25. It will include an address by Dr. A. T. James, of the National Institute for Medical Research, on "Applications of Gas Chromatography to Some Medical Problems". Further information can be obtained from Dr. H. Jasperson, c/o J. Bibby and Sons, Ltd., Research Department, King Edward Street, Liverpool 3.

Errata. Two mistakes in the list of new Fellows of the Royal Society of Edinburgh (Nature, Mareh 18, p. 876) have been pointed out: Dr. K. B. Fraser is senior lecturer in bacteriology (not botany) in the University of Aberdeen; and the name of Dr. C. H. Gimingham, senior lecturer in botany in the University of Aberdeen, was omitted. 